University of Nebraska - Lincoln

DigitalCommons@University of Nebraska - Lincoln

Faculty Papers and Publications in Animal

Science

Animal Science Department

February 2002

\title{
Estimation of genetic parameters for milk, fat, protein and mozzarella cheese production for the Italian river buffalo Bubalus bubalis population
}

\author{
A. Rosati \\ Associazione Italiana Allevatori (A.I.A.), Via Nomentana 134, 00162 Rome, Italy \\ L. Dale Van Vleck \\ University of Nebraska-Lincoln, dvan-vleck1@unl.edu
}

Follow this and additional works at: https://digitalcommons.unl.edu/animalscifacpub

Part of the Animal Sciences Commons

Rosati, A. and Van Vleck, L. Dale, "Estimation of genetic parameters for milk, fat, protein and mozzarella cheese production for the Italian river buffalo Bubalus bubalis population" (2002). Faculty Papers and Publications in Animal Science. 113.

https://digitalcommons.unl.edu/animalscifacpub/113

This Article is brought to you for free and open access by the Animal Science Department at DigitalCommons@University of Nebraska - Lincoln. It has been accepted for inclusion in Faculty Papers and Publications in Animal Science by an authorized administrator of DigitalCommons@University of Nebraska - Lincoln. 


\title{
Estimation of genetic parameters for milk, fat, protein and mozzarella cheese production for the Italian river buffalo Bubalus bubalis population
}

\author{
A. Rosati ${ }^{\mathrm{a}, \mathrm{c}, *}$, L.D. Van Vleck ${ }^{\mathrm{b}, \mathrm{c}}$ \\ ${ }^{a}$ Associazione Italiana Allevatori (A.I.A.), Via Nomentana 134, 00162 Rome, Italy \\ ${ }^{\mathrm{b}}$ Roman L. Hruska U.S. Meat Animal Research Center, ARS, USDA, Lincoln, NE 68583-0908, USA \\ ${ }^{\mathrm{c}}$ Department of Animal Science, University of Nebraska, Lincoln, NE 68583-0908, USA
}

Received 11 January 2001; received in revised form 2 July 2001; accepted 21 July 2001

\begin{abstract}
The objective of this work was to estimate genetic parameters for the Italian population of river buffaloes. Lactation records $(10,663)$ for milk, fat, protein and mozzarella cheese production of river buffalo cows were analyzed by fitting a multiple trait animal model using restricted maximum likelihood. The number of cows with records was 3873 with 6842 animals in the relationship matrix. mozzarella cheese production per lactation was computed by considering milk yield, and fat and protein percentages. The average lactational yields of milk, fat, protein and calculated mozzarella $(\mathrm{kg})$ and fat and protein percentages were $2286.8 \pm 492.1,196.9 \pm 45.6,104.7 \pm 21.7,589.1 \pm 125.4,8.59 \pm 0.85$ and $4.55 \pm 0.28$, respectively. Heritability estimates for milk, fat, protein and mozzarella yields and fat and protein percentages were $0.14,0.11,0.14,0.13$, 0.17 and 0.10 , respectively. Though estimates of heritability are lower than for the same traits in dairy cattle, estimates of phenotypic and genetic correlations between all traits show the possibility of developing a selection scheme to improve characteristics of milk for production of mozzarella cheese, the most important product of Italian buffaloes. (ㄷ 2002 Elsevier Science B.V. All rights reserved.
\end{abstract}

Keywords: Genetic correlation; Selection; Heritability; Buffalo

\section{Introduction}

\subsection{Breeding and management of river buffaloes}

The world population of domestic buffaloes,

\footnotetext{
*Corresponding author. Present address: Associazione Italiana Allevatori (A.I.A.), Via Nomentana 134, 00162 Rome, Italy. Tel.: +39-06-8545-1304; fax: +39-06-8545-1322.

E-mail address: rosati.a@aia.it (A. Rosati).
}

Bubalus bubalis, is estimated to be more than 150 million (Bhat, 1992). Two main types of domestic buffalo are the river buffalo and the swamp buffalo. River buffalo live in a geographical belt from India in the east to Italy in the west, passing through Pakistan, Iran, Turkmenistan, Iraq, Syria, Egypt, Azerbaijan, Turkey, Greece, Bulgaria and the former Yugoslavia. In recent times buffaloes, mainly from India and from Italy, have been exported to Central and South America. The river buffalo is mainly 
reared for milk production. Murrah in India, Nili Ravi and Kundi in Pakistan, Beheri and Saidi in Egypt and Italian and Shumen in Europe are well known types of river buffalo. About half of the world's buffalo population lives in India. Swamp buffaloes are reared for draught and for meat. Because buffaloes are able to stay in water when temperature is high, they are more adapted to hot and humid climates than many breeds.

Buffaloes in the Mediterranean area are large in size and, if well fed, have relatively high milk production. About 200,000 buffaloes are estimated to be currently in Italy. Almost all buffalo milk production is transformed to mozzarella cheese, an expensive fresh cheese. Thus the buffalo milk price is about three times that of milk of dairy cattle. A characteristic of river buffalo is the high percentage of both protein and fat in the milk, although average milk yield per lactation is quite low if compared to dairy cattle.

In Italy most buffalo farms are in the south. Buffaloes are raised on fertile lowlands and in improved areas with access to stables in unfavorable weather. Traditionally little attention was given to calf rearing because of the longevity of buffalo cows and because no importance was given to buffalo meat. The annual herd replacement rate is now 15$18 \%$. Age at first calving is $1206 \pm 365$ days while the calving interval for the first four calvings is 440.7 \pm 38.9 days. Length of pregnancy $(311.0 \pm 1.2$ days) is $\sim 1$ month longer than for cattle (Associazione Italiana Allevatori, 1998). Age at first positive conception is estimated to be $\sim 29-30$ months. Fertility is largely influenced by the season. The natural tendency is to calve in late summer. Most buffaloes are bred by natural mating mainly because heat detection is difficult. Nevertheless artificial insemination is increasingly used with frozen semen.

\subsection{Genetic studies of river buffaloes}

Most genetic analyses of productive traits of buffaloes have been conducted in India and Pakistan. Significant effects of parity order for milk yield were found by Arona et al. (1962). Milk yield was also reported to increase from first to sixth parity (Sane et al., 1972). Another study showed an increase in milk yield from the first to a peak in the fourth lactation (Patro and Bhat, 1979) and that milk yield, even in the ninth lactation, is relatively close to peak production. Significant effects of year and season of milk yield have been reported (Patro and Bhat, 1979; Reddy and Taneja, 1984; Mahdy et al., 1999). Significant effects associated with farm also have been described by Kumar and Bhat (1978) and Reddy and Taneja (1984). Bhat and Batro (1978) reported the effects on milk yield of age and weight at calving and preceding dry period. Age at calving had a significant positive effect up to the third lactation. Weight at calving had a significant effect up to the fifth lactation while an effect of preceding service period was found up to the fourth period. A large portion of the variability in yield is explained by lactation length (Bhat and Batro, 1978). Heritability estimates for the Indian population of buffaloes for first lactation milk yield have ranged from 0.08 to 0.65 (Bhat, 1992). In an Egyptian experiment heritability estimates ranged from $0.03 \pm 0.08$ to $0.20 \pm 0.13$ for total milk yield in parities one to five and repeatability across parities was $0.50 \pm 0.03$. The estimated heritability across parities for total milk yield was $0.11+0.05$ (Mourad and Mohamed, 1995).

Milk produced by buffalo cows is usually rich in fat and protein (Table 1). Buffalo milk is richer in both fat and protein percentages than dairy cattle and zebu cattle milk. Singh et al. (1979) found fat percentage was influenced by year and season, while

Table 1

Summary of production for records in the analyses (270 days)

\begin{tabular}{lccccc}
\hline & Average & Unadjusted S.D. & Minimum & Maximum & Records \\
\hline Milk (kg) & 2286.8 & 492.1 & 702.2 & 5061.1 & 10,663 \\
Fat (kg) & 196.9 & 45.6 & 65.5 & 495.2 & 10,313 \\
Fat $(\%)$ & 8.59 & 0.85 & 5.15 & 13.26 & 10,313 \\
Protein (kg) & 104.7 & 21.7 & 35.0 & 213.3 & 9441 \\
Protein (\%) & 4.55 & 0.28 & 3.13 & 6.46 & 9441 \\
Mozzarella (kg) & 589.1 & 125.4 & 208.7 & 1301.2 & 9420 \\
\hline
\end{tabular}


the effect of parity was not found to be significant. Protein percentage was found to be highly heritable, 0.42 , by Pal et al. (1971). In the same analysis repeatability estimates were 0.71 for fat and 0.74 for protein percentages. Phenotypic correlations among all constituents (fat, protein, lactose, ash, total solids, solids-not-fat and casein percentages) were positive, ranging from 0.28 to 0.97 . Negative estimates were found for phenotypic correlations between milk yield and all percentage components, while estimates of phenotypic correlation were positive between all component yields and milk yield.

\subsection{Breeding strategies for Italian buffalo population}

The Italian Animal Breeders Association maintains a selection scheme to increase milk yield. Registration in the herd book totals 28,400 animals (Associazione Italiana Allevatori, 1998). Milk records of buffalo cows are taken with the A4 system, which is two samples a day taken about once a month. Each year 18 male calves are raised in a bull station. About six young bulls are culled for morphological or fertility reasons. Semen is obtained from the remaining 12 bulls in an amount sufficient for progeny testing with frozen system. The young bulls are then progeny tested on registered farms and semen of the best proved bulls is used for all cows by artificial insemination.

\section{Materials and methods}

\subsection{Description of data}

Records of lactation yields from 1980 to 1995 were available. All production records were projected to a conventional lactation length of 270 days. Editing consisted of accepting only lactations having more than 120 and less than 700 days of lactation and from cows having a known registered sire and dam with a total of more than four paternal halfsisters on at least two farms. No records after the eighth parity were considered. Only 11,864 lactations were usable after editing mainly because of the limited use of A.I. Milk, fat and protein yields $(\mathrm{kg})$ and fat and protein percentages were measured monthly. Because of the importance of the mozzarel- la cheese market, estimated production of mozzarella cheese for a lactation was analyzed as another trait which was estimated from the observations on milk, fat and protein, by a formula reported by Altiero et al. (1989):

$$
\begin{aligned}
\text { mozzarella }(\mathrm{kg})= & (\text { milk, } \mathrm{kg}) *[3.5 *(\text { protein, } \%) \\
& +1.23 *(\text { fat }, \%)-0.88] / 100
\end{aligned}
$$

The formula shows that increased production of mozzarella cheese can be obtained mainly by increasing milk yield and protein percent. Fat percentage has less influence on mozzarella cheese production than protein percentage.

\subsection{The model}

All traits were analyzed using the same animal model. Herd and year combinations with 584 levels were considered as fixed effects together with calendar month of calving with 12 levels, and number of times of milking per day with two levels, that is one or two milking per day. A cubic covariate was used to adjust for age in days at calving and a quadratic covariate was used to adjust for days in the previous dry period for second and later lactations. Animal genetic and permanent environmental random effects were associated with cows. In summary the model was:

$\boldsymbol{y}=\boldsymbol{X} \boldsymbol{\beta}+\boldsymbol{Z u}+\boldsymbol{W p}+\boldsymbol{e}$

where $\boldsymbol{y}$ is vector of one of the traits; $\boldsymbol{X}$ is is the matrix that associates $\boldsymbol{\beta}$ with $\boldsymbol{y} ; \boldsymbol{\beta}$ is vector of fixed effects of herd-year, number of times milked per day, calendar month of calving, covariates for age at calving and covariates for preceding dry period; $\boldsymbol{Z}$ is is the matrix that associates $\boldsymbol{u}$ with $\boldsymbol{y} ; \boldsymbol{u}$ is is the vector of breeding values for direct genetic effects with numerator relationship matrix, $\boldsymbol{A} ; \boldsymbol{W}$ is the matrix that associates $\boldsymbol{p}$ with $\boldsymbol{y} ; \boldsymbol{p}$ is is the vector of permanent environmental effects of the cows, and $\boldsymbol{e}$ is the vector of residual temporary environmental effects not explained by other parts of the model.

Estimates of variance components were obtained using a multiple-trait derivative-free REML program (Boldman et al., 1993). Heritability and genetic and environmental correlations among traits were estimated from the components of variance and covariance. For the six traits analyzed the multiple-trait 
animal model was an expansion of the single-trait model. The covariances parameters were estimated from bivariate analyses of pairs of traits.

\section{Results and discussion}

\subsection{Genetic parameters}

Estimates of variance components and genetic parameters for milk, fat, protein yields, and mozzarella cheese yields and percentages of fat and protein are shown in Table 2. All estimates of genetic parameters seem to be low, especially if compared to estimates from similar analyses for dairy cattle. Buffaloes have not been intensively selected in the past, so greater genetic variability among animals would be expected. Some possible causes of low estimates of genetic parameters can be addressed. There is traditionally considerable variability in management both among and inside herds. The model can only partially account for management variability. The variation in production can be assigned mainly to environmental effects causing low heritability estimates. Though editing on data was done before the analysis to exclude cows without known sire and dam, some wrong genealogy may be present. Misleading paternity identification with the animal model would result in assigning part of the genetic variability to environmental effects and would reduce the estimate of heritability for direct genetic effects. The Italian buffalo population has also experienced changes over time. The large population in the Italian peninsula until the end of the last century contracted to a small number to reach a minimum $\sim 40$ years ago. Since then population size has increased. The current population might have originated from a very small group of animals causing low genetic variability.

The low estimate of heritability for mozzarella production, as for all other traits, indicates that progress due to selection might be slow if traditional selection schemes are used to improve quantity and quality of milk to produce mozzarella cheese. Better identification will improve the genetic trend of the population. Alternative selection schemes that make use of techniques to overcome the problem of misleading genealogies may need to be further developed.

\subsection{Correlations among traits}

Estimates of genetic, permanent and temporary environmental correlations are shown in Tables 3 and 4. Estimates of genetic correlations between traits are similar to those that can be found in the literature for dairy cattle. Large estimates for genetic correlations between milk, fat and protein yields are commonly reported for dairy cattle (Barker and Robertson, 1966). The small negative genetic correlations between milk yield and each of protein and fat percentages indicate that milk yield can be increased through selection without large decreases in quality of milk. A selection goal for the buffalo population is production of milk to obtain mozzarella cheese. The objective of selection can be reached by increasing the production of milk with optimum percentages of fat and protein to be processed to

Table 2

Estimates of variance components and genetic parameters

\begin{tabular}{lcclclc}
\hline Parameter & Milk yield $(\mathrm{kg})$ & Fat yield $(\mathrm{kg})$ & Fat $(\%)$ & Protein yield $(\mathrm{kg})$ & Protein $(\%)$ & Mozzarella yield $(\mathrm{kg})$ \\
\hline$\sigma_{\mathrm{u}}^{2}$ & 21,493 & 132 & 0.099 & 43.5 & 0.006 & 1271 \\
$\sigma_{\mathrm{p}}^{2}$ & 38,040 & 200 & 0.163 & 72.1 & 0.007 & 2126 \\
$\sigma_{\mathrm{e}}^{2}$ & 96,341 & 897 & 0.306 & 198.7 & 0.047 & 6488 \\
$\sigma_{\mathrm{t}}^{2}$ & 155,874 & 1229 & 0.569 & 314.3 & 0.060 & 9886 \\
$h^{2}$ & 0.14 & 0.11 & 0.17 & 0.14 & 0.10 & 0.13 \\
$c^{2}$ & 0.24 & 0.16 & 0.29 & 0.23 & 0.12 & 0.22 \\
$e^{2}$ & 0.62 & 0.73 & 0.54 & 0.63 & 0.78 & 0.65 \\
\hline
\end{tabular}

$c^{2}$, proportion of variance due to permanent environmental effects; $e^{2}$, proportion of variance due to temporary environmental effects; $h^{2}$, heritability of genetic effects; $\sigma_{\mathrm{e}}^{2}$, variance due to temporary environmental effects; $\sigma_{\mathrm{p}}^{2}$, variance due to permanent environmental effects; $\sigma_{\mathrm{t}}^{2}$, total phenotypic variance; $\sigma_{\mathrm{u}}^{2}$, variance due to additive genetic effects. 
Table 3

Estimates of genetic correlations among traits

\begin{tabular}{|c|c|c|c|c|c|c|}
\hline & Milk yield (kg) & Fat yield (kg) & Fat $(\%)$ & Protein yield (kg) & Protein $(\%)$ & Mozzarella yield $(\mathrm{kg})$ \\
\hline Milk yield (kg) & - & 0.88 & -0.08 & 0.95 & -0.12 & 0.95 \\
\hline Fat yield (kg) & & - & 0.41 & 0.38 & 0.44 & 0.54 \\
\hline Fat $(\%)$ & & & - & -0.04 & 0.31 & 0.62 \\
\hline Protein yield (kg) & & & & - & 0.65 & 0.66 \\
\hline Protein $(\%)$ & & & & & - & 0.87 \\
\hline
\end{tabular}

Table 4

Estimates of correlations among traits for permanent (above diagonal) and temporary environmental effects (below diagonal)

\begin{tabular}{lccclcc}
\hline & Milk yield $(\mathrm{kg})$ & Fat yield $(\mathrm{kg})$ & Fat $(\%)$ & Protein yield $(\mathrm{kg})$ & Protein $(\%)$ & Mozzarella yield $(\mathrm{kg})$ \\
\hline Milk yield $(\mathrm{kg})$ & - & 0.94 & -0.55 & 0.97 & -0.51 & 0.54 \\
Fat yield $(\mathrm{kg})$ & 0.85 & - & -0.24 & 0.13 & -0.02 & 0.69 \\
Fat $(\%)$ & -0.16 & 0.36 & - & 0.61 & 0.82 & 0.04 \\
Protein yield $(\mathrm{kg})$ & 0.93 & 0.51 & 0.21 & - & -0.15 & 0.98 \\
Protein $(\%)$ & -0.21 & 0.01 & 0.21 & 0.31 & - & -0.03 \\
Mozzarella yield $(\mathrm{kg})$ & 0.72 & -0.10 & 0.51 & 0.76 & 0.45 & - \\
\hline
\end{tabular}

make mozzarella cheese. The breeding values for mozzarella production can be considered as a kind of selection index because all available information about the individual is used. A large estimate of genetic correlation between mozzarella production with milk yield was expected because milk yield is the main component of the formula used to compute mozzarella production for a lactation. For the same reason all other yield traits have positive genetic correlations with yield of mozzarella cheese.

\section{Conclusions}

Weight of mozzarella cheese estimated from observations on other traits can be used as a selection criterion to improve overall economic return. Relatively small estimates of genetic variance were found for all traits analyzed, including mozzarella cheese production, resulting in low heritability estimates. Small estimates might be due to inaccurate identification of true paternity. Utilization of artificial insemination needs to be increased in order to increase genetic exchange among herds and to increase rate of genetic improvement. Consideration should be given to further study of the fraction of incorrect parental identification. Improvement in identification of parents might be a cost-effective way to increase heritability and to increase the rate of genetic improvement. If that is not the reason for low heritability and accuracy of selection, then new strategies for selection may need to be found in order to improve buffalo for mozzarella production more rapidly than with traditional means.

\section{References}

Altiero, V., Moio, L., Addeo, F., 1989. Previsione della resa in mozzarella sulla base del contenuto in grasso e proteine del latte di bufala. Scienza Tecnica Lattiero-Casearia 40 (6), 425 433.

Arona, S.P., Bajpai, L.D., Muley, A.R., 1962. Influence of dry period on milk yield and effects on lactation yield and lactation days of Murrah buffaloes. J. Vet. Anim. Husbandry Res. Mhow $5,51-55$.

Associazione Italiana Allevatori (A.I.A), 1998. Controlli della Produttività del Latte. A.I.A, Rome, Italy.

Barker, J.S.F., Robertson, A., 1966. Genetic and phenotypic parameters for the first three lactations in Friesian cows. Anim. Prod. 8, 221-240.

Bhat, P.N., 1992. Genetics of river buffaloes. In: Tulloh, N.M., Holmes, J.H.G. (Eds.), Buffalo Production. Elsevier, Amsterdam, pp. 13-58.

Bhat, P.N., Batro, B.N., 1978. Effect of various non-genetic factors on milk yield and lactation length in Indian buffaloes. Indian J. Dairy Sci. 31, 321-325.

Boldman, K.G., Kriese, L.A., Van Vleck, L.D., Kachman, S.D., 1993. A Manual For Use of MTDFREML. A Set of Programs To Obtain Estimates of Variances and Covariances. ARS USDA, USMARC, Clay Center, NE. 
Kumar, R., Bhat, P.N., 1978. Effect of some non-genetic sources of variation on milk yield in Indian buffaloes. Indian J. Anim. Sci. 48, 639-642.

Mahdy, A.E., El Shafie, O.M., Ayyat, M.S., 1999. Genetic study and sire values for some economic traits in Egyptian buffaloes. Alexandria J. Agricultural Res. 44 (2), 15-35.

Mourad, K.A., Mohamed, M.M., 1995. Genetic and phenotypic aspects of milk yield traits and reproductive performance of Egyptian buffaloes. Egyptian J. Anim. Prod. 32 (2), 125-137.

Pal, S., Basu, S.B., Sengar, O.P.S., 1971. Heritabilities and genetic correlations for milk constituents in Murrah buffaloes. Indian J. Anim. Sci. 41, 1019-1021.
Patro, B.N., Bhat, P.N., 1979. Inheritance of production traits in buffaloes. Indian J. Anim. Sci. 49, 10-14.

Reddy, C.E., Taneja, V.K., 1984. Phenotypic, genetic and environmental trends for age at first calving in Murrah buffaloes. Asian J. Dairy Res. 3, 60-62.

Sane, D.D., Khanna, R.S., Bajpai, L.D., Bhat, P.N., 1972. Studies on Murrah buffalo (Bubalus bubalis). II. Genetic analysis of milk yield and peak yield. Indian J. Anim. Prod. 3 (2), 61-65.

Singh, A., Basu, S.B., Bathia, K.L., 1979. Milk fat and SNF percentages of Murrah buffaloes. Indian J. Anim. Sci. 32, $446-449$. 